\title{
Electronic cell counting to measure total cell numbers in bronchoalveolar lavage fluid
}

\author{
L.G. Heaney*†, J. McKirgan**, C.F. Stanford*, M. Ennis ${ }^{\dagger}$,
}

\begin{abstract}
Electronic cell counting to measure total cell numbers in bronchoalveolar lavage fluid. L.G. Heaney, J. McKirgan, C.F. Stanford, M. Ennis. CERS Journals Ltd 1994.

ABSTRACT: Cell counting of bronchoalveolar lavage (BAL) fluid is performed manually in routine practice. This has both methodological and inherent errors; however, the accuracy and suitability of automated counting devices have been questioned. In this study, a Coulter ${ }^{\circledR}$ Counter D Industrial model was calibrated and then used to measure the total cell count in unprocessed bronchoalveolar lavage fluid, and compared to a standard manual method.

Bronchoalveolar lavage was performed on 34 patients undergoing routine bronchoscopy. An aliquot of unprocessed bronchoalveolar lavage fluid was taken for all counting procedures. Manual counts were performed blind by two experienced independent observers using improved Neubauer chambers. Electronic counting measured $1 \mathrm{ml}$ aliquots suspended in 10 and $20 \mathrm{ml}$ Isoton ${ }^{\circledR}$ counting 0.5 and $1 \mathrm{ml}$ duplicates.

The correlation coefficients between electronic and manual counts were good. The coefficients of repeatability of electronic counts, for repeat counts, both on the same dilution (Intra-Coulter ${ }^{\circledR}: \mathbf{0 . 1} \times \mathbf{1 0}^{5}$ cells $^{-} \mathbf{m l}^{-1}$ ) and different dilutions (InterdilutionCoulter ${ }^{\circledR}: 0.48 \times 10^{5}$ cells $\cdot \mathrm{ml}^{-1}$ ), were superior compared to those for repeat manual counts by the same observer $\left(1.03 \times 10^{5}\right.$ cells $\left.\cdot \mathrm{ml}^{-1}\right)$, and counts between observers $\left(1.82 \times 10^{5}\right.$ cells $\left.\cdot \mathrm{ml}^{-1}\right)$.

This method offers a quick, precise and simple method for counting cells in unprocessed bronchoalveolar lavage fluid, which is both less labour intensive and subjective than manual counting.

Eur Respir., 1994, 7, 1527-1531.
\end{abstract}

\begin{abstract}
Depts of *Respiratory Medicine and **Immunology, The Royal Victoria Hospital Belfast, UK. †Dept of Clinical Biochemistry, The Queen's University of Belfast, Belfast UK.
\end{abstract}

Correspondence: L.G. Heaney Dept of Clinical Biochemistry Institute of Clinical Science

The Queen's University of Belfast Grosvenor Road

Belfast, BT12 6BJ UK

Keywords: Bronchoalveolar lavage cell counts

Received: December 171993 Accepted after revision April 131994

LGH is funded with a Department of Health and Social Services research fellowship.
The total cell count in bronchoalveolar lavage (BAL) fluid is routinely measured by a manual method, such as haemocytometry, and expressed as the number of cells per unit volume. Manual methods have been superseded in the assessment of haematological cell parameters by automated counters, because of superior repeatability and the avoidance of the many sources of potential error which exist with manual methods [1]. A satisfactory automated counting method has not been described for BAL and certain groups have highlighted the problems with automated methods. The International Conference on BAL (1984) and the European Society of Pneumology Task Group on technical aspects of BAL (1989), concluded that automated counters, such as a Coulter ${ }^{\circledR}$ Counter, may underestimate the total cell count because the broad range of cell sizes present in lavage fluid may lie outside the window settings of a given counter $[2,3]$. Other groups have also found an electronic gating method unreliable $[4,5]$ due, specifically, to an underestimation of macrophages, the predominant cell type in BAL $[4,5]$. One study using a Coulter® Counter S-Plus STKR [6] concluded that the automated counter tended to give a higher count than manual counting; however, in this study, the cells were concentrated by centrifugation prior to counting, a process which is now widely accepted as causing variable cell loss [3-5, 7].

We describe the use of a Coulter ${ }^{\circledR}$ Counter D Industrial model to measure the cell count in unprocessed BAL fluid and compare it to a standard manual technique.

\section{Material and methods}

\section{Calibration of Coulter Counter}

Electronic cell counting was performed using a Coulter ${ }^{\circledR}$ Counter D Industrial model (Coulter Electronics, UK). As with other Coulter ${ }^{\circledR}$ counters, it consists of two electrodes immersed in an electrically conductive liquid, communicating via a fixed diameter aperture, through which a current flows. Particles when forced through this aperture, cause a transient change in resistance, which in turn causes a voltage pulse 
directly related to the particle volume. The voltage pulses are amplified and fed to a threshold circuit, and both degree of amplification and threshold setting can be adjusted. An aperture of $140 \mu \mathrm{m}$ was used in the system, as smaller apertures tended to occlude with mucus during counting. The effects of variation in the amplification, threshold and aperture current are wellestablished $[8,9]$, and are related by the formula: $\mathrm{v}=$ $\mathrm{k} \times \mathrm{A} \times \mathrm{I} \times \mathrm{t}$, where $\mathrm{v}$ is the particle volume, $\mathrm{I}$ is the aperture current (milliamperes), $\mathrm{t}$ is the threshold, $\mathrm{A}$ is the attenuation (which is the reciprocal of the amplification), and $\mathrm{k}$ is a constant for the system. The diluent for all counting procedures was a standard isotonic solution, Isoton ${ }^{\circledR}$ (Coulter Electronics, UK), and standardized latex particles (mean diameter 67.8 femtolitres (fl), maximum coefficient of variation 13\% (Coulter Electronics, UK)) were used to calibrate the machine. Latex particles (3 drops) were suspended in Isoton ${ }^{\circledR}(20 \mathrm{ml})$.

Initially, the aperture current was set at 1 , the attenuation at 8 and threshold at 20, in accordance with the calibration procedure. The former two dials (aperture current and attenuation) were adjusted to give a deflection of $2 \mathrm{~cm}$ on the oscilloscope for the majority of pulses. The counts at various thresholds were measured in triplicate and a threshold curve plotted. The appropriate true count threshold is taken as the mid-plateau value [9]. Lymphocytes are the smallest leucocytes in BAL fluid, and their mean volume in blood when measured using two independent methods (lymphocrit/ lymphocyte count and a weight/density method) was found to be 200-220 fl [10]. By substituting this value in the above equation, the appropriate settings to count all nucleated cells in lavage fluid can be calculated. To assess the ability of the machine to avoid counting erythrocytes, blood from three normal volunteers was diluted (in isotonic saline) to give erythrocyte concentrations of $10^{5}$ and $10^{4}$ cells $\cdot \mathrm{ml}^{-1}$. One millilitre aliquots of these were then added to $10 \mathrm{ml}$ of Isoton ${ }^{\circledR}$ as for BAL fluid, and the true count of erythrocytes in each dilution obtained by plotting threshold curves. The count at the BAL settings was expressed as a percentage of the true count.

\section{Patients}

Patients ( $\mathrm{n}=34,24$ male, 26 smokers, mean age $60 \pm$ 2 yrs) undergoing routine bronchoscopy were recruited to the study. The final diagnosis in the subjects was 16 haemoptysis with no endobronchial abnormality, 10 bronchogenic carcinoma, 4 resolving pneumonia, 2 chronic cough, 1 cryptogenic fibrosing alveolitis and 1 with a pyrexia of unknown origin. All subjects with a localized pulmonary abnormality had involvement of the left lung only.

All patients had a standardized lavage performed. After premedication with $0.3-0.6 \mathrm{mg}$ atropine given intravenously, topical lignocaine (4\%) was applied to the oropharynx. The bronchoscope was passed nasally and $2 \%$ lignocaine applied via a cannula to the vocal cords. Further local anaesthesia was achieved with 1\% lignocaine, as required. The bronchoscope was wedged in a segmental orifice of the right middle lobe and lavage $(3 \times 60 \mathrm{ml})$ performed with sterile isotonic saline, inserted under minimum hand pressure. After minimum dwell time, the fluid was aspirated into a plastic container and the return samples pooled into a polypropylene vessel, which was placed on ice.

\section{Processing of BAL specimens}

The pooled lavage sample was carefully mixed and an aliquot $(10 \mathrm{ml})$ withdrawn. This was again well mixed and two further aliquots $(2 \mathrm{ml})$ withdrawn. These aliquots were given to two experienced independent observers (observers Nos 1,2), who performed blind manual counts using an improved Neubauer chamber (BDH Ltd, UK). Observer No. 1 performed a repeat count after refilling the haemocytometer and also counted erythrocytes, if present, in the lavage sample.

The remaining fluid from the original $10 \mathrm{ml}$ aliquot was used to perform electronic counts using two separate dilutions $\left(1 \mathrm{ml} \mathrm{BAL}\right.$ fluid in $10 \mathrm{ml}$ Isoton ${ }^{\circledR}$, and $1 \mathrm{ml}$ in $20 \mathrm{ml}$ Isoton $\left.{ }^{\circledR}\right)$. Differential cell counting was also performed on this aliquot using the glass coverslip centrifuge method [11], followed by staining with Diff-Quik.

\section{Statistical methods}

All results are given as the mean $( \pm$ SEM) unless stated otherwise. Method comparison is performed according to Bland and Altman [12], with assessment of both agreement and repeatability. To measure agreement, measurements are made with both methods, followed by calculation of the mean difference and 95\% confidence intervals of the differences. The $95 \%$ confidence intervals represent the "limits of agreement" and in effect, provided differences within these limits are acceptable, the methods are interchangeable. Coefficient of repeatability, as defined by the British Standards Institution, is the value below which $95 \%$ of repeat measurements will lie using a given method, and represents two standard deviations of the mean differences of repeat measurements on the same sample [12].

Intramanual repeatability is defined as the repeatability in cell count of the same aliquot in a refilled chamber and counted by the same observer, and intermanual repeatability as the repeatability in cell count of the same sample counted by different observers. Intra-Coulter ${ }^{\circledR}$ repeatability is defined as the repeatability in cell count performed on the same dilution twice, and interdilution Coulter ${ }^{\circledR}$ repeatability as the repeatability in cell count using the two different dilutions.

\section{Results}

\section{Calibration of the Coulter ${ }^{\circledR}$ Counter}

Using latex particles suspended in $20 \mathrm{ml}$ of Isoton ${ }^{\circledR}$, the threshold curve was plotted and the mid-plateau 


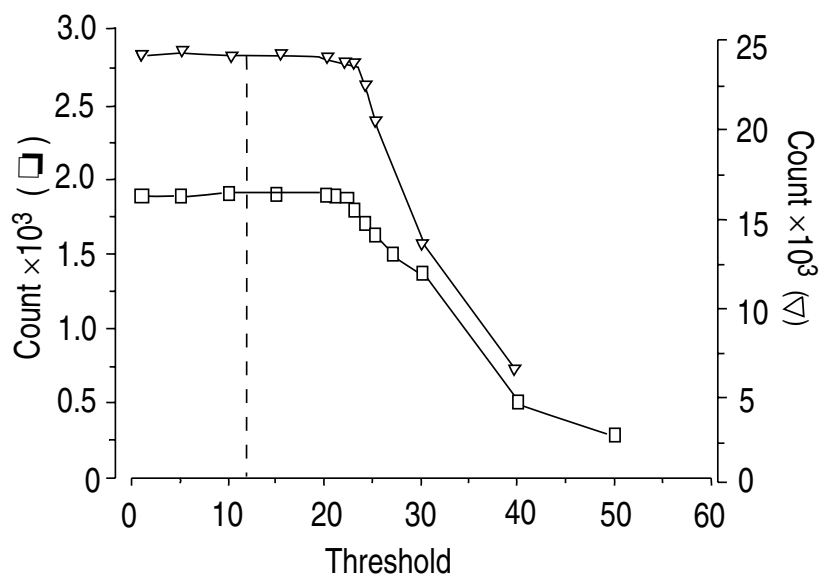

Fig. 1. - Electronic counting of standard latex particles (mean volume 67.8 fl, maximum coefficient of variation 13\%) using a Coulter Counter (D Industrial model), with attenuation set at 2 and aperture current set at 0.0033 . Using two different concentrations of latex particles $\left(\square: 10^{5} \cdot \mathrm{ml}^{-1} ; \Delta: 10^{4} \cdot \mathrm{ml}^{-1}\right)$ the count threshold is 12 (mid-plateau).

value found to be 12 (fig. 1). Using this value, the value of $\mathrm{k}$ for our system was calculated as 856 . Thus, with a mean lymphocyte volume of $220 \mathrm{fl}$ and setting the attenuation at 2 and the aperture current at 0.0093 , the calculated threshold value is $13.8(\approx 14)$ to perform cell counts in BAL fluid. Calibration should be performed weekly according to the manufacturer's recommendations, but in our experience no drift in calibration settings occurred.

Using the above settings, the machine counted less than $4 \%(3.6 \pm 0.1 \%)$ of the erythrocytes in solution (fig. 2).

Comparison between manual and electronic counts of total cell numbers in BAL fluid

The mean differential cell count for this study group was: macrophages $82.6 \pm 2.2 \%$; neutrophils $5.3 \pm 0.1 \%$;

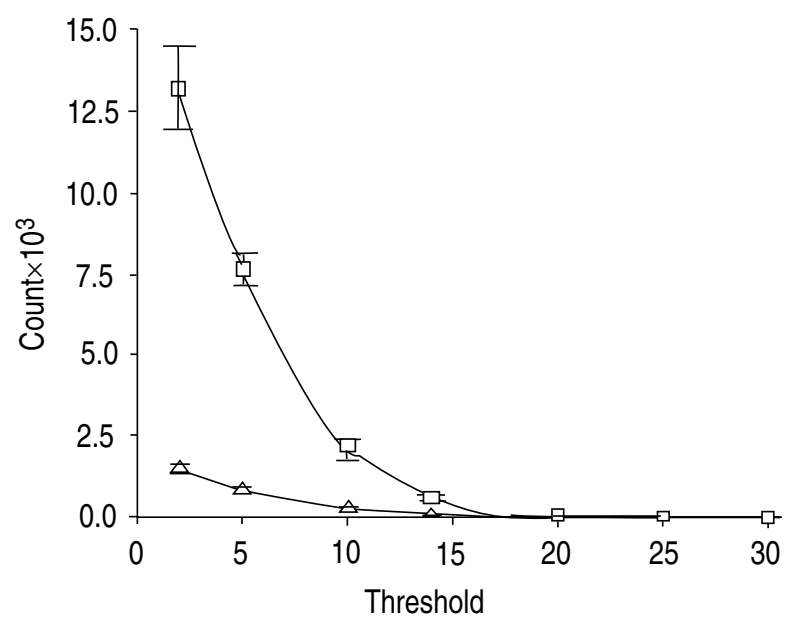

Fig. 2. - Threshold curve for normocytic erythrocytes $\left(\Delta: 10^{4} \cdot \mathrm{ml}^{-1}\right.$. $\left.\square: 10^{5} \cdot \mathrm{ml}^{-1}\right)$ in isotonic saline, with attenuation set at 2 and aperture current set at 0.0093 . Values are shown as mean \pm SEM $(n=3)$. At $\mathrm{t}=14$ (BAL settings), mean red cell count is equal to $3.6 \pm 0.1 \%$ true count at both concentrations. BAL: bronchoalveolar lavage; t: threshold. a)

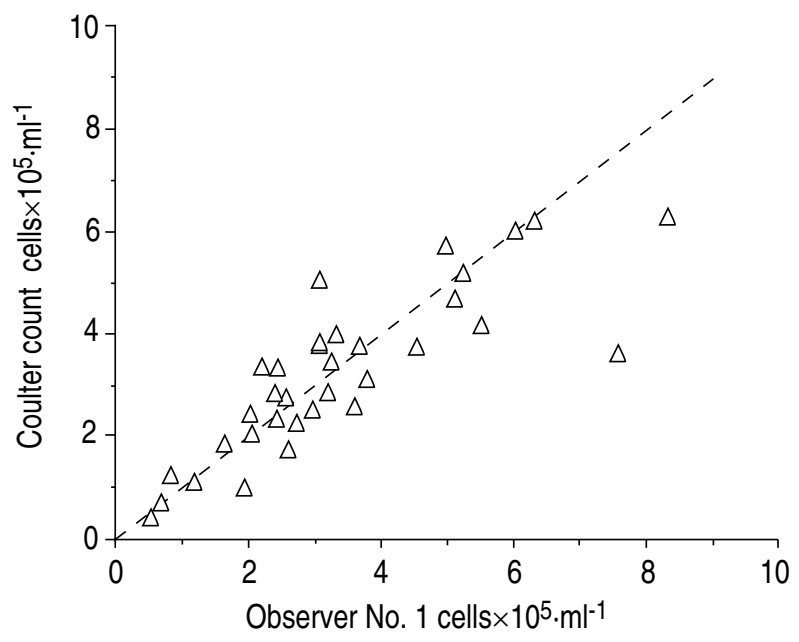

b)

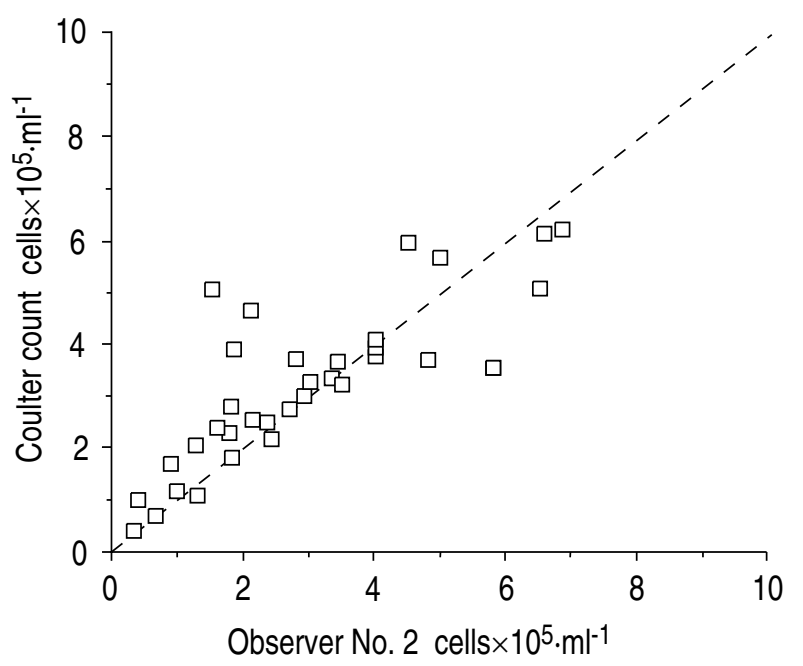

Fig. 3. - Correlation between manual counts and electronic counts for: a) observer No. $1(\mathrm{r}=0.84 ; \mathrm{p}<0.0001 ;)$ and $\mathrm{b})$ observer No. 2 $(\mathrm{r}=0.81 ; \mathrm{p}<0.0001)$. - - -: line of identity.

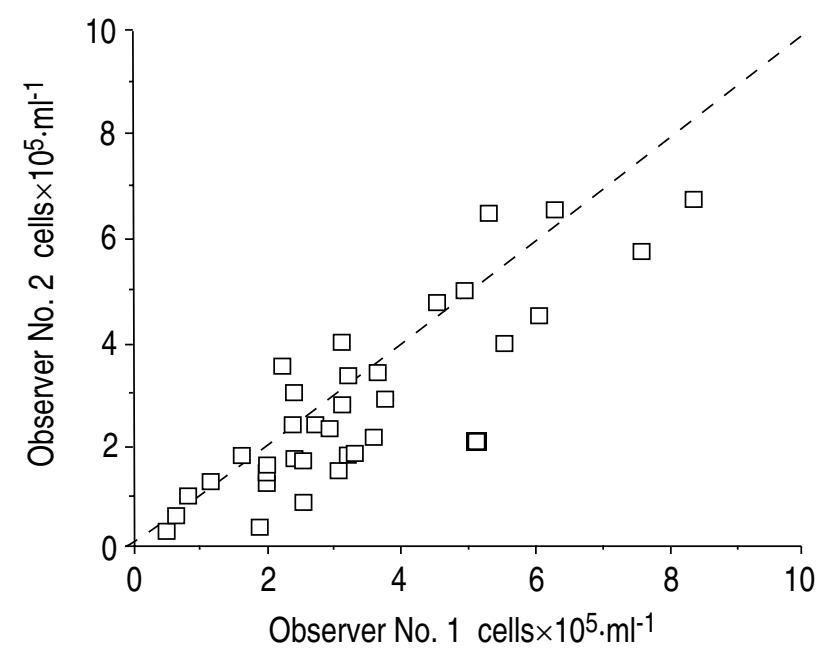

Fig. 4. - Correlation between manual counts (observer No. 1 and observer No. 2) $(\mathrm{r}=0.86 ; \mathrm{p}<0.0001) . \quad-\quad \div$ line of identity. 
lymphocytes $7.3 \pm 1.3 \%$; eosinophils $0.7 \pm 0.2 \%$; epithelial cells $4.7 \pm 1.3 \%$. The mean erythrocyte $(n=34)$ count obtained by haemocytometry was $2.0 \pm 0.5 \times 10^{5}$ cells $\cdot \mathrm{ml}^{-1}$. For the lavage fluid, there was a good correlation between the results of the Counter and both observer No. $1(\mathrm{r}=0.84 ; \mathrm{p}<0.0001)$ (fig. 3a) and observer No. 2 ( $\mathrm{r}=0.81$; $\mathrm{p}<0.0001)$ (fig. $3 \mathrm{~b}$ ). There was also a good correlation between both manual counts $(r=0.86 ; p<0.0001)$ (fig. $4)$. The limits of agreement between the counter and observer No. 1 were $-1.88-2.19 \times 10^{5}$ cells $\cdot \mathrm{ml}^{-1}$ and with observer No. $2,-2.32-1.68 \times 10^{5}$ cells $\cdot \mathrm{ml}^{-1}$. Intramanual repeatability was $1.03 \times 10^{5} \cdot \mathrm{ml}^{-1}$ and intermanual repeatability $1.82 \times 10^{5} \cdot \mathrm{ml}^{-1}$. Intra-Coulter ${ }^{\circledR}$ repeatability was $0.10 \times 10^{5} \cdot \mathrm{ml}^{-1}$ and interdilution Coulter ${ }^{\circledR}$ repeatability $0.48 \times 10^{5} \cdot \mathrm{ml}^{-1}$.

\section{Discussion}

The results demonstrate that a Coulter® Counter D Industrial model can produce results for total cell count which correlate well with manual methods but which have greater repeatability. The calculation of limits of agreement allows better comparison between two methods [12]. If the differences within the limits of agreement are acceptable, then the methods are interchangeable, but because the total cell count in nonsmokers lies between $1.0-2.0 \times 10^{5}$ cells $\cdot \mathrm{ml}^{-1}$ [4], our results suggest marked differences will occur between results obtained using both methods. Many sources of error exist in the manual counting procedure, including variation in the loading volume, the speed of chamber filling, concentration of cells opposite the site of loading, and cell aggregates failing to enter the chamber [1]. Manual counts also have an inherent error due to the random distribution of cells in the chamber, which causes variation in the numbers of cells distributed in areas of equal size. The resultant error is related to the actual number of cells counted [1]. With electronic counters, the larger volume used and the greater number of cells counted reduces many of these errors, resulting in superior repeatability. In this study, repeat counts using the Coulter ${ }^{\circledR}$ Counter on a given sample were better when compared to the manual method and, furthermore, the repeatability of manual counts by experienced observers on the same sample was poor. Interdilution Coulter ${ }^{\circledR}$ repeatability was good and represents the repeatability of all procedures involved in the method described including pipetting, sample dilution, and the counting process itself. Cell dispersion occurs quickly and settling is not a problem as long as counting is done within 5-10 min of preparation [8].

Previous reports [3-5] regarding electronic counting of cells in BAL fluid have found an underestimation of the total white cell count, mostly due to an undercounting of macrophages. Our method does not define an upper size limit or threshold on counting and, thus, macrophage undercounting is not a problem. This is reflected in the current study, as the predominant cell type in all samples was the macrophage and a tendency to undercount was not observed. Erythrocyte contamination can also lead to errors if significant numbers of these are included in the total count. From the calibration curves with normocytic erythrocyte preparations less than $4 \%$ of the erythrocytes present in the sample will be counted at our calibration settings. In the lavage specimens, the mean erythrocyte count by haemocytometry was $2.0 \pm 0.54 \times 10^{5}$ cells $\cdot \mathrm{ml}^{-1}$ so the overall error introduced by erythrocyte counting in this series is small and compares favourably with the inherent error of manual counting. A concentration of $10^{6}$ erythrocytes $\cdot \mathrm{ml}^{-1}$ in saline is clearly bloodstained to the naked eye and, thus, any sample of BAL which is obviously bloodstained will not be suitable for this method. However, such bloodstaining would also contribute white cells from the intravascular compartment and would make interpretation of the differential cell count difficult. Such a sample would not be suitable for research purposes or routine clinical evaluation. The current study, however, shows that in standard BAL samples the electronic method is comparable to the manual method and requires less expertise, and is much less labour intensive.

Bronchoalveolar lavage is widely used for research purposes into a wide variety of pulmonary processes and the total and differential cell counts in the return fluid are basic parameters which are routinely reported. The lavage procedure itself and cell processing after lavage vary from centre to centre and, recently, much work has focused on the variability due to these differences. Cell processing is widely accepted as causing variable cell loss $[2-5,7]$, and in one recent review the marked variability in reported cell counts in asthma was highlighted [5]. Little attention, however, has focused on the method of measuring total cell count, and most centres use haemocytometry to enumerate this value $[2,3,5]$.

Single threshold counters cost between $£ 5,000$ and $£ 10,000$, depending on the exact specifications. However, once purchased they can be utilized for many research and routine applications. High quality microscopes, necessary for manual counting, also cost several thousand pounds and the maintenance and running costs of both are comparable. Electronic counting is faster and operator independent and, thus, has a potential cost/benefit advantage in addition to superior precision.

The use of total cell count in the assessment of bronchial inflammatory processes has been questioned because of the wide variability seen in normal subjects. Total cell count in healthy volunteers is not normally distributed [13]. A large multicentre study examining how differences in age, gender, race, lavage volume return and current smoking history in a normal population affected lavage results concluded that these factors must be tightly controlled and that a standardized lavage protocol must be used to ensure that data both within a given study and from centre to centre are comparable [14]. In particular, they suggested cells in lavage fluid should be expressed as both total cells $\cdot \mathrm{ml}^{-1}$ and a percentage differential cell count, otherwise results could be misleading. Studies examining lavage samples from normal volunteers, concluded that total cell count, whether expressed as total cells recovered or cells $\cdot \mathrm{ml}^{-1}$, showed 
both large intersubject variability [15], and significant variation when performed serially in the same individual [16]. In these studies, however, cells were processed prior to counting, by filtering through gauze and centrifugation, both of which cause variable and significant cell loss $[2-5,7]$. Total cell counts were enumerated by manual methods, and we have demonstrated that one of these manual methods in itself has poor intra- and interobserver repeatability. These studies have questioned the usefulness of the total cell count as a worthwhile parameter in lavage fluid, however, given the current results, this may have to be reassessed.

In conclusion, electronic counting offers a quick, precise and simple method for counting nucleated cells in unprocessed lavage fluid. It is less labour intensive and less subjective than the routine manual counting method.

Acknowledgements: The authors are grateful to P.V. Gardiner for helpful discussions, and the medical and nursing staff of the bronchoscopy suites of the Royal Victoria and Belfast City Hospitals, Belfast for their cooperation.

\section{References}

1. Hall R, Malia RG. Basic haematological practice. In: Medical Laboratory Haematology. 2nd edn. Oxford, Butterworths, 1991; pp. 84-112.

2. Crystal RG, Reynolds HY. Bronchoalveolar lavage. The report of an International Conference. Chest 1984; 90: 22-131.

3. Klech H, Pohl W. Technical recommendations and guidelines for bronchoalveolar lavage (BAL). Eur Respir $J$ 1989; 2: 561-585.

4. Saltini C, Hance AJ, Ferrans VJ, Basset F, Bitterman PB, Crystal RG. Accurate quantification of cells recovered by bronchoalveolar lavage. Am Rev Respir Dis 1984; 130: 650-658.

5. Walters EH, Gardiner PV. Bronchoalveolar lavage as a research tool. Thorax 1991; 46: 613-618.
6. Braun S, Breyer O, Reinert U. Kann die elektronische Messung der Gesamtzellzahl in der bronchoalveolaren Lavage die herkommliche Kammerzählung ersetzen? Pneumologie 1990; 44: 295-296.

7. Mordelet-Dambrine M, Arnoux A. Processing of lavage fluid causes variability in bronchoalveolar cell count. Am Rev Respir Dis 1984 130: 305-306.

8. Mattern CFT, Brackett FS, Olson BJ. Determination of number and size of particles by electrical gating: blood cells. J Appl Physiol 1957; 10: 56-70.

9. Freshney RI. Quantitation and experimental design. In : Culture of Animal Cells. A Manual of Basic Technique. 2nd edn. New York, Alan R Liss, 1988; pp. 227244.

10. Segel GB, Cokelet GR, Lichtman MA. The measurement of lymphocyte volume: importance of reference particle deformability and counting solution tonicity. Blood 1981; 57: 894-899.

11. Laviolette M, Carreau M, Coulombe R. Bronchoalveolar lavage cell differential on microscope glass cover. Am Rev Respir Dis 1988; 138: 451-457.

12. Bland JM, Altman DG. Statistical methods for assessing agreement between two methods of clinical measurement. Lancet 1986; i: 307-310.

13. Merchant RK, Schwartz DA, Helmers RA, Dayton CS, Hunninghake GW. Bronchoalveolar lavage cellularity: the distribution in normal volunteers. Am Rev Respir Dis 1992; 146: 448-453.

14. Cherniack RM, Banks DE, Bell DY, Davis GS, Hughes JM, King TE. Bronchoalveolar lavage constitutents in healthy individuals, idiopathic pulmonary fibrosis, and selected comparison groups. Am Rev Respir Dis 1990; 141: S169-S202.

15. Ettenson DB, Jankowski MJ, Duncan PG, Lalor PA. Bronchoalveolar lavage in the normal volunteer subject: 1. Technical aspects and intersubject variability. Chest 1988; 94: 275-280.

16. Banks DE, Morgan JE, Deshazo RD, et al. Reliability of cell counts and protein determinations in serial bronchoalveolar lavage procedures performed on healthy volunteers. Am J Med Sci 1990: 300: 275-282. 